\title{
KLF1 Gene
}

National Cancer Institute

\section{Source}

National Cancer Institute. KLF1 Gene. NCI Thesaurus. Code C84289.

This gene is involved in both transcriptional regulation and erythrocyte differentiation. 